a specific topic. The presentations are also available by viewing the programs on the past meetings pages.

\section{Update Your AATS Profile}

Check that the information in your aats.org profile is current to ensure that you are receiving AATS information that is most important to you. By updating your contact information and sharing your areas of interest, you will be able to optimize your use of AATS Online and receive relevant AATS news. While you are in your profile, you can upload a recent photo, view your AATS activity, and more. To access your profile, log in using the "Sign In" or "My Account" link at the top of aats.org.

\section{The AATS Foundation}

\section{An Invitation to Impact the Future}

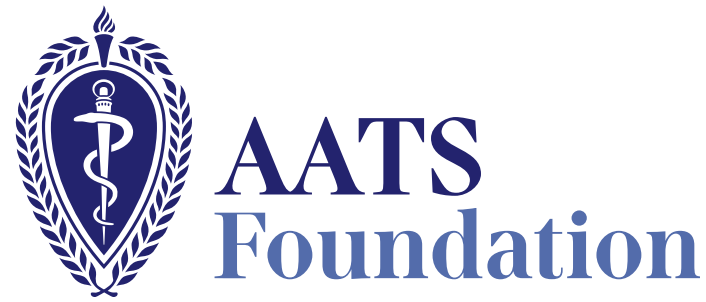

Thank you to those who have shown that you understand the importance of giving generously to support the next generation of cardiothoracic surgeons. As the end of the fiscal year quickly approaches, we challenge you to donate and underwrite the scholarship that advances the mission.

December 31st is fast approaching, and we are asking you to please consider donating to the AATS Foundation. Donors like you will be funding programs that promote excellence in clinical care and, ultimately, improve patient outcomes. Your support provides practicing surgeons, fellows, and residents with opportunities to enhance their overall surgical knowledge and technical skills.

Recently, the overwhelming support of many donors fulfilled the AATS $\$ 250,000$ matching grant. Believing strongly in investing in the mission of the AATS Foundation, AATS leadership has issued a new matching grant. Every individual, one-time gift of $\$ 5,000$ or more will be doubled, making each dollar you contribute twice as valuable.

Learn more about the various ways to make a gift on aatsfoundation.org. Your gift will profoundly impact the future of cardiothoracic surgery around the world.

\section{Opportunities Available}

Visit aats.org to learn more about the following programs that are accepting applications from mid-October to January 15, 2020. Contact admin@aats.org for additional questions.

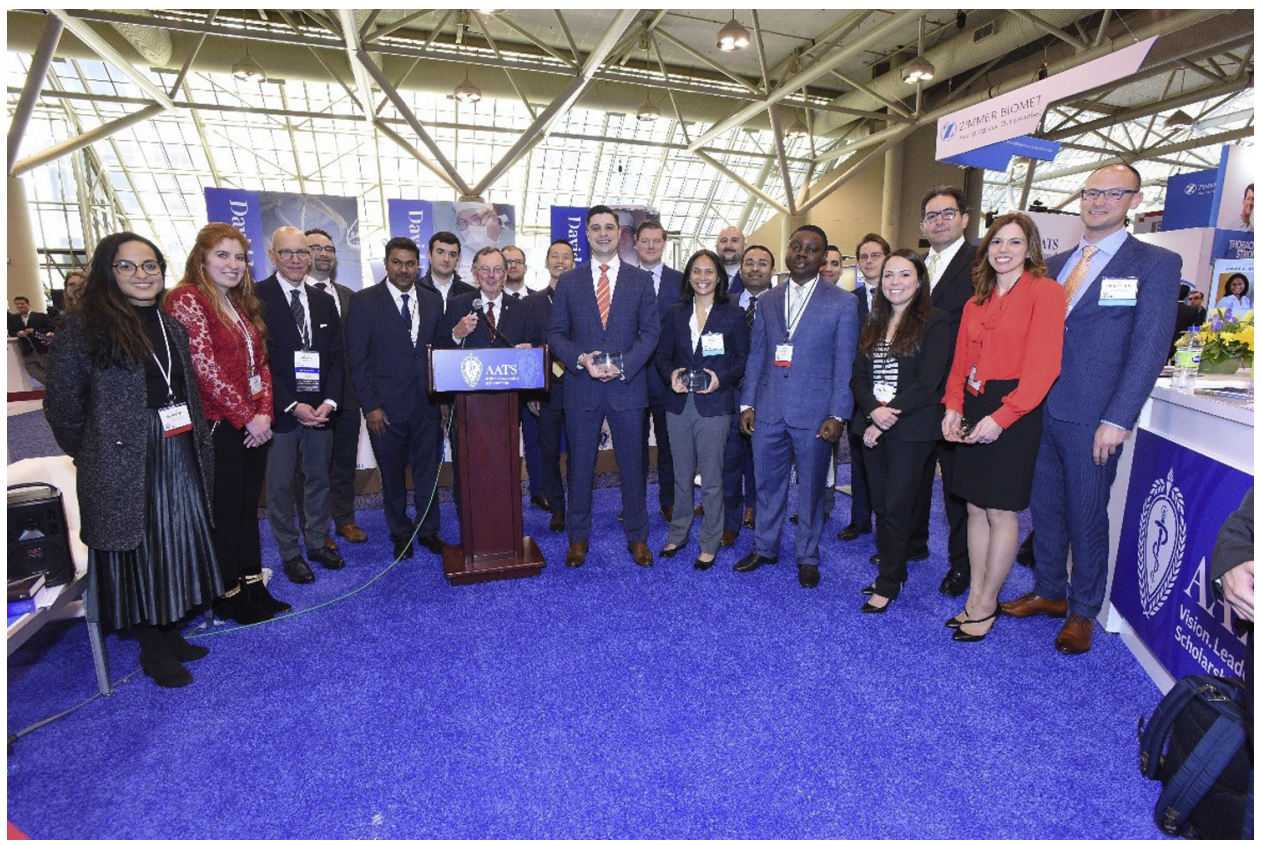




\section{AATS Member for a Day Award}

Accompany an AATS Member Mentor during portions of the AATS 100th Annual Meeting through the AATS Member for a Day Award. You will have the opportunity to gain insight into the cardiothoracic surgery specialty as well as network and build relationships within the cardiothoracic surgical community. You will also receive complimentary all-access registration to the scientific sessions at the Annual Meeting, as well as the AATS Member for a Day Session and the AATS/TSRA Resident Luncheon.

Apply to be one of the North American medical students, general surgery residents, up to third year integrated cardiothoracic surgery residents (I-6) and members of the American Physician Scientists Association (APSA) chosen to participate in the program.

\section{AATS Cardiothoracic Surgery Resident Poster Compe- tition}

Senior cardiothoracic surgery residents and/or congenital heart surgery fellows from around the world have the opportunity to present a scientific poster of their clinical/ investigative research at the 100thAnnual Meeting in
New York, NY. To represent your institution in the AATS Resident Poster Competition, provide a brief abstract (no more than 300 words) regarding the research. Posters may include research that has been previously presented and/or published.

\section{Perioperative/Team-Based Care Poster Competition}

Non-MD cardiothoracic surgical team professionals can participate in the AATS Perioperative/Team-Based Care Poster Competition at the AATS 100th Annual Meeting taking place in New York, NY. The posters should reflect the participant's research findings and/or new and innovative ideas for successful approaches in the management of the cardiothoracic patient. Abstracts previously presented at a national or international meeting may be submitted. The purpose of the competition is to present research findings and share new and innovative ideas for successful approaches in the management of the cardiothoracic patient. To be eligible for the program, cardiothoracic perioperative/team-based care professionals (NPs, PAs, Perfusionists, and RNs) must submit their abstract electronically through the submission site on the AATS Web site.

\section{The Western Thoracic Surgical Association}

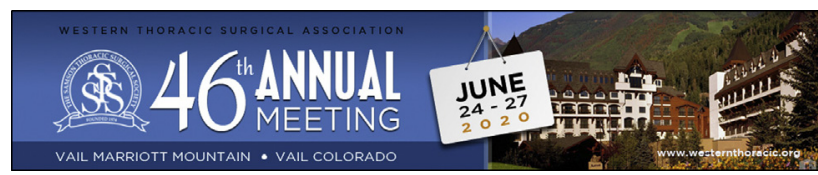

\section{WTSA 46th Annual Meeting}

\author{
Save the Date for the WTSA 46th Annual Meeting \\ June 24-27, 2020 \\ Vail Marriott Mountain \\ Vail, Colorado
}

\section{WTSA Traveling Fellowship for Residents, Trainees, and Practicing Surgeons}

Application Deadline: December 15, 2019.

The goal of this traveling fellowship is to promote interaction and learning between residents/trainees/ practicing surgeons and WTSA members. The traveling fellow will visit a University-affiliated or academic practice of his/her choosing, within the boundaries of the WTSA
(Alaska, Arizona, California, Colorado, Hawaii, Idaho, Montana, Nevada, New Mexico, Oregon, Utah, Washington, and Wyoming, along with Canadian provinces of Alberta, British Columbia, Manitoba, and Saskatchewan), for a period of one to two weeks, under the sponsorship of a Western member at the hosting institution. The traveling fellow does not need to be a WTSA member; the award is open to any resident/trainee/practicing surgeon. More details are available at westernthoracic.org.

\section{Applications for WTSA Membership}

Application Deadline: March 1, 2020.

The WTSA is now accepting Applications for Membership online for Active as well as Candidate membership status for the 2020 membership cycle. Visit the WTSA Web site at www.westernthoracic.org to read the complete membership eligibility requirements and to initiate an online application.

\section{Active Member}

$\$ 375.00$ annually, plus $\$ 50.00$ initiation fee

Applicant must meet all membership criteria, including but not limited to:

- Reside within or have completed a cardiothoracic residency training program within the geographic limits of the Association. 